\title{
IMPLEMENTASI PENDIDIKAN KARAKTER DI PESANTREN MODERN EL-ALAMIA DENGAN MEMBERIKAN KETELADANAN DAN PEMBIASAAN
}

\author{
Sanudin Ranam ${ }^{1}$, Ibnu Fiqhan Muslim ${ }^{2(*)}$, Priyono $^{3}$ \\ Universitas Indraprasta PGRI, Jakarta, Indonesia ${ }^{123}$ \\ sanudinranam@gmail.com ${ }^{1}$, fiqhanmuslimibnu@gmail.com ${ }^{2}$, priyono.unindra@gmail.com
}

\begin{tabular}{ll}
\hline & \\
Received: & 12 Desember 2020 \\
Revised: & 29 Januari 2021 \\
Accepted: & 08 Maret 2021
\end{tabular}

\section{Abstract}

Accepted: 08 Maret 2021

Pendidikan karakter merupakan segala usaha yang dilakukan oleh seseorang di keluarga, sekolah dan masyarakat untuk membangun karakter dari peserta didik agar memiliki karakter yang baik atau mempunyai kepedulian, berpendirian, dan bertanggung jawab. Menyikapi pentingnya hal tersebut, pendidikan karakter diperlukan di sebuah pondok pesantren untuk mewujudkan peradaban bangsa dengan memberikan keteladanan dan pembiasaan. Pondok pesantren menjadi tempat belajar formal sekaligus nonformal yang mampu banyak memberikan perubahan terhadap karakter peserta didik melalui pembiasaan yang dilakukan selama peserta didik menimba ilmu di pesantren. Pendidikan karakter merupakan upaya yang dilakukan dalam mendidik sesorang yang dapat membantu membentuk/menguatkan karakter seseorang yang dilakukan di lingkungan keluarga sekolah, dan lingkungan dengan memanfaatkan media belajar. Tujuan dari penelitian ini yaitu untuk mengetahui implementasi yang sudah dilakukan oleh Pondok Pesantren El Alamia, Bogor. Metode yang digunakan adalah metode penelitian kualitatif sebagai suatu penelitian ilmiah. Hasil penelitian ini adalah terdapat lima fokus pendidikan karakter yang terdapat di Pondok Pesantren El Alamia. Pendidikan karakter religius, nasionalis, integritas, mandiri, dan gotong royong. Dengan memiliki kelima karakter tersebut, diharapkan para santri di Pondok Pesantren El Alamia dapat menghadapi tantangan dan perkembangan zaman.

Keywords: Pendidikan karakter; Keteladanan; Pembiasaan

(*) Corresponding Author: $\quad$ Muslim, fiqhanmuslimibnu@gmail.com, +62 895345291840

How to Cite: Ranam, S., Muslim, I. F., \& Priyono. (2021). Implementasi Pendidikan Karakter Di Pesantren Modern El-Alamia Dengan Memberikan Keteladanan Dan Pembiasaan. Research and Development Journal of Education, 7 (1), 90-100.

\section{INTRODUCTION}

Indonesia adalah salah satu negara yang memiliki musuh besar, yaitu kemiskinan, kebodohan, merajalelanya korupsi, perundungan, dan tawuran. Adanya perilaku-perilaku negatif yang terjadi di masyarakat membutuhkan perhatian kita dan masyarakat tentunya. Persoalan-persoalan tersebut timbul disebabkan oleh pudarnya nilai-nilai karakter bangsa. Elfindri (2011), "Anomaly adalah hal yang berkebalikan dari yang seharusnya terjadi." Pendidikan karakter adalah hal yang penting dalam kurikulum pendidikan di Indonesia sejak tahun 2013. Pendidikan di Indonesia dipandang hanya dapat membentuk intelektual, tetapi tidak dibarengi dengan pendidikan moral peserta didik. Adanya kasus tersebut menjadikan pemerintah mendesain kurikulum yang baru. Kemudian, pada tahun 2013 pemerintah membuat kurikulum baru yang berfokus pada pembentukan karakter peserta didik. 
Indonesia merupakan negara yang membutuhkan sumber daya manusia sebagai pendukung utama pembangunan negara dengan jumlah dan mutu memadai. pendidikan mempunyai andil yang penting, untuk memenuhi sumber daya manusia tersebut. Pendidikan nasional mempunyai tujuan agar potensi peserta didik berkembang menuju arah yang baik. Dengan pendidikan yang lebih baik, Indonesia akan menjadi negara yang masyarakatnya memiliki karakter yang kuat. Pendidikan juga mempunyai tujuan membuat pembelajar menjadi lebih cerdas, mandiri, dan memiliki karakter yang kuat sesuai dengan falsafah ideologi bangsa.

Pendidikan merupakan upaya yang dilakukan secara sadar dan direncanakan agar terwujud kondisi pembelajaran supaya pembelajar secara aktif menggali kemapuan yang ada pada dirinya agar mempunyai ketahanan spiritual keagamaan, dapat mengendalikan diri, mempunyai kepribadian, kecerdasan, akhlakulkarimah, serta keterampilan yang dibutuhkan pembelajar itu sendiri, masyarakat luas, dan negara. Jalur pendidikan merupakan solusi yang dipandang dapat menjadi jalan keluar untuk masalah tersebut. Pendidikan sebagai tindakan preventif karena melalui pendidikan akan terbentuk angkatan/penerus baru yang bisa lebih baik. Menanggapi urgensi akan hal tersebut, dibutuhkan pendidikan yang menekankan pada karakter di pondok pesantren untuk mewujudkan peradaban.

Berdasarkan Pancasila, terdapat lima nilai karakter pokok dalam penguatan pendidikan karakter. Kelima karakter tersebut adalah fokus pengembangan Penguatan Pendidikan Karakter (PPK); yaitu religius, integritas, nasionalisme, kegotongroyongan dan kemandirian. Dari lima nilai karakter tersebut saling memiliki keterkaitan dan tidak bisa sendiri-sendiri berdiri.Untuk mereliasasikannya hal itu diperlukan kerja sama antara pihak sekolah dan orang tua.

Mulyasa (2012) menyebutkan bahwa saat anak dilahirkan ke dunia, bayi sudah mengalami perkembangan otak sebesar $25 \%$,sampai ketika umur empat tahun perkembangannya mencapai $50 \%$,dan ketika delapan tahun sudah $80 \%$, selanjutnya berkembang hingga usia 18 tahun. Oleh karena itu, pondok pesantren sebagai lembaga pendidikan memiliki peran penting dalam penguatan karakter. Pondok pesantren El Alamia adalah salah satu pondok pesantren di Kota Bogor yang memedulikan Pendidikan Penguatan Karakter santri. Pondok pesantren ini memiliki santri/siswa yang memiliki latar belakang dari beberapa daerah di Indonesia. Di dalam pondok pesantren seorang santri bisa meniru atau meneladani para pendidik baik itu guru maupun teman di dalam pondok pesantren. Di pondok pesantren pula, seorang santri/siswa dibiasakan untuk melakukan hal-hal yang tentunya bisa membuat karakter yang ada dalam dirinya semakin kuat. Pondok pesantren mengatur segala aktivitas belajar dan aktivitas harian santri/siswa. Dengan pembiasaan tersebut akan mampu membentuk/menguatkan karakter santri/siswa yang mengikuti seluruh rangkaian kegiatan pondok pesantren.

\section{LITERATURE REVIEW}

\section{Pendidikan Karakter}

Kata karakter adalah kata dari bahasa Yunani, yaitu karasso yang mempunyai aarti cetak biru, format dasar, dan sidik seperti dalam sidik jari. Orang yang mempunyai karakter kuat adalah orang yang tidak dipengaruhi oleh sekumpulan kenyataan yang sudah ada. Lain halnya dengan orang dengan karakter lemah. Orang dengan karakter lemah biasanya orang yang patuh pada beberapa situasi yang sudah dihadapi tanpa dapat mengendalikannya (Koesoema, 2011). Megawangi (Dharma, 2011) menyebutkan pendidikan karakter merupakam kegiatan dalam mendidik peserta didik supaya dapat 
menentukan keputusan yang lebih bijak dan mempraktikkannya dalam kegiatan seharihari sehingga dapat memberikan andil untuk lingkungannya.

Pendidikan berarti usaha dalam mendewasakan sikap dan perilaku peserta didik agar menjadi manusia yang lebih baik. Pendidikan merupakan usaha dalam membantu peserta didik supaya dapat menjalani kehidupan sesuai dengan tujuan hidupnya. Pendidikan menyadarkan peserta didik untuk peduli terhadap dirinya, orang lain, dan lingkungannya. Sesuai dengan maksud pendidikan yaitu upaya yang dilakukan secara sadar dan direncanakan agar dapat mengimplementasikan pembelajaran supaya pembelajar secara aktif menggali potensi yang ada dalam dirinya.

Pendidikan karakter adalah upaya yang dilakukan oleh pihak sekolah, bahkan dapat dilakukan dengan kerja sama dengan orang tua/wali dan masyarakat untuk mendorong anak-anak dan remaja supaya mempunyai sifat bertanggung jawab, berpendirian, dan peduli (Daryanto, 2013). Dari beberapa pengertian para ahli dapat diambil kesimpulan yaitu pendidikan karakter merupakan proses pengubahan sifat, akhlak, budi pekerti, mental, dan jiwa orang atau dari beberapa orang agar berkembang lebih dewasa.

Terdapat lima pendidikan karakter pokok yang bersumber dari Pancasila. Hal ini menjadi elemen pengembangan pendidikan karakter; yaitu religius, integritas, nasionalisme , kegotongroyongan dan kemandirian. Dari kelima nilai tersebut tidak mungkin karakter itu berdiri sendiri dan berkembang sendiri, tetapi saling berkaitan, berkembang dinamis dan tentunya membentuk pribadi yang utuh.

Nilai karakter religius merupakan cerminan sikap iman kepada Tuhan YME, perwujudannya dalam perilaku menunaikan perintah agama dan kepercayaan yang dipeluk. Karakter religius juga terlihat dalam menjunjung tinggi perilaku toleran mengenai peribadahan agama lain, menghargai perbedaan agama, hidup rukun dengan pemeluk agama yang berbeda. Perwujudan pendidikan karakter religius dapat terlihat dalam sikap toleransi, menghargai perbedaan agama, mencintai kedamaian, memiliki ketangguhan dalam pendirian, percaya diri, bisa bekerja sama antarpenganut agama dan kepercayaan.

Nilai karakter nasionalis merupakan pola berpikir manusia dalam perbuatan yang dapat memperlihatkan kesetiaan, bersikap kepedulian, dan apresiaso yang tinggi kepada bahasa, lingkungan fisik, budaya, ekonomi, sosial, dan politik bangsa. Nilai karakter ini meletakkan kepentingan bangsa di atas kepentingan diri sendiri dan kelompok. Sikap nasionalis tersebut dapat diperlihatkan melalui sikap melestarikan budaya bangsa, rela berkorban, menghargai budaya bangsa sendiri, unggul, memberikan toleransi keragaman budaya, agama, suku, berprestasi, mencintai bangsa, menaati hukum, displin, dan menjaga lingkungan.

Nilai karakter integritas adalah nilai yang mejadi dasar perilaku dan upaya menjadikan orang tersebut agar menjadi orang yang dapat dipercaya ketika berkata, bekerja dan bertindak. Orang yang punya integritas mempunyai tanggung jawab dan kesetiaan terhadap nilai kemanusiaan dan moral. Karakter ini memiliki ciri sikap tanggung jawab warga negara, aktif berkontribusi dalam kehidupan sosial, merealisasikan ketetapan dan kemantapan dalam bertindak dan berrkata berdasarkan kebenaran. Seseorang yang berintegritas mengindahkan martabat individu, serta mampu memperlihatkan teladan.

Nilai karakter berupa kemandirian merupakan sikap sesorang yang tidak menggantungkan dirinya kepada orang di sekelilingnya. Orang yang mandiri menggunakan segala tenaga dan pikirannya dalam mewujudkan harapan dan cita-cita. Seseorang yang mandiri memiliki jiwa dan semangat kerja yang baik, berdaya juang tinggi, tangguh, profesional, kreatif, memiliki keberanian, dan menjadi pembelajar. 
Nilai karakter berupa kegotongroyongan memperlihatkan perilaku menghargai terhadap semangat kerja sama untuk menyelesaikan permasalahan secara bersama-sama, mewujudkan komunikasi dan persahabatan, melakukan tindakan menolong orang-orang yang membutuhkan.Seseorang yang dapat mememiliki sikap dapat bekerja sama, menghargai sesama, musyawarah mufakat, tolong menolong, mampu melakukan sesuatu atas keputusan bersama, mempunyai empati, antikekerasan, antidiskriminasi, dan sikap rasa solidaritas. (kemdikbud, 2017)

\section{Pembiasaan dan Keteladanan}

Djaali (2013) menyampaikan dengan pembiasaan yaitu dengan cara bertindak yang dilakukan dengan belajar secara berulang-ulang, dan pada akhirnya menetap dan bersifat otomatis. Amin (2015) menyebutkan ada indikator dalam pembiasaan. Indikator tersebut sebagai berikut: (1) Rutin dengan tujuan agar anak menjadi terbiasa melakukan sesuatu. (2) Spontan yang memiliki tujuan memberikan pendidikan dengan tanpa direncanakan, terutama dalam membuat anak terbiasa sopan santun. (3) Keteladanan, yang mempunyai tujuan untuk memberi teladan kepada anak. Menurut Hasan (2012) mengemukakan petunjuk/tanda kedisiplinan yaitu sebagai berikut : (1) Ketika datang tepat waktu (2) Dapat memprediksi waktu yang dibutuhkan dalam menyelesaikan pekerjaan (3) Mempergunakan alat sesuai fungsinya (4) Mengambil alat dan meletakkannya kembali pada tempatnya (5) Berusaha menaati peraturan yang sudah disepakati (6) Tertib dalam menunggu dalam giliran (7) Sadar akan dampak jika tidak disiplin.

Keteladanan adalah elemen mutlak dalam melakukan perubahan perilaku hidup, dalam mempersiapkan serta membentuk moral spiritual dan sosial anak. Untuk itu, contoh atau teladan yang paling baik dari pandangan anak yang dapat dicontoh dalam perilaku dan sopan santunnya tertanam dalam jiwa. Keteladanan ini sesuai untuk mengembangkan nilai karakter dan sosial pada anak. Artinya, nasihat tanpa diiringi dengan keteladanan akan sia-sia. Hakikat pembiasaan berisikan pengalaman. Pembiasaan adalah sesuatu yang diamalkan. Oleh karena itu pembiasaan dapat didefinisikan pengulangan. Dalam pembinaan sikap, pembiasaan menjadi lebih ada efeknya jika digunakan dalam melatih kebiasaan-kebiasan yang baik kepada anak pada usia dini. Sifat pendidikan kepada anak dalam usia dini adalah mencontoh sesuatu yang dilakukan oleh orang sekitar baik oleh bapak dan ibunya maupun saudara terdekat. Oleh sebab itu, orang tua/wali sebaiknya menjadi sosok atau contoh yang terbaik di mata anaknya. Apabila orang tua menginginkan anak tumbuh dengan melakukan kebiasaan yang baik dan akhlak terpuji, orang tua harus menjadi teladan bagi anaknya.

Keteladanan (panutan) merupakan sikap yang dapat dipercaya dengan tujuan mewujudkan kepercayaan. Fungsi keteladanan adalah memberikan contoh bagaimana agar seorang pemimpin menjadi teladan/contoh bagi para bawahannya, dan juga bagaimana pemimpin bertanggung jawab atas tutur katanya. Keteladanan seseorang dapat terlihat melalui beberapa hal yaitu, tutur kata, tutur kata merupakan perkataan yang disampaikan menggunakan bahasa yang sopan dan santun supaya lawan bicara/mitra tutur tidak tersinggung. Tutur kata merupakan suatu yang penting dalam hal komunikasi yang dilakukan sehari-hari baik dengan teman yang sebaya, lebih muda atau lebih tua, sikap sebagai kesediaan dalam bereaksi dalam hal yang positif/negatif pada objek-objek tertentu, perilaku manusia merupakan perilaku yang dimiliki oleh manusia, dan melakukan apa yang dikatakan dalam hal ini pemimpin dituntut untuk bisa melakukan apa yang dikatakannya atau sejauh manaseorang pemimpin mampu menyesuaikan

Dalam dunia pendidikan formal dan non formal guru menjadi panutan bagi peserta didiknya. Guru sebagai pekerja profesional disiapkan untuk mendidk anak-anak yang 
telah di amanatkan orang tua untuk dapat mendidik anaknya di sekolah. Guru atau pendidik menjadi orang tua dan bertanggung jawab dalam memberikan pendidikan yang lebih baik kepada peserta didik.

\section{METHODS}

Pada penelitian ini, peneliti menggunakan penelitian lapangan (field research) karena didasarkan pada data-data yang terkumpul secara langsung kelapangan untuk melakukan pengamatan ketempat objeknya yaitu di Pesantren Modern El-Alamia. Pendekatan yang digunakan yaitu pendekatan deskriptif kualitatif, yaitu metode penelitian yang bertujuan untuk menjelaskan data berupa kata- kata, gambar dan bukan angka- angka. Peneliti menggunakan analisis induktif, yaitu menganalisa mulai dari faktor-faktor khusus, kemudian fakta yang ditemukan diolah kemudian dibuat kesimpulan yang memiliki sifat umum.

Penelitian ini dilakukan di Pesantren Modern El-Alamia. Adapun subjek didalam penelitian ini yaitu kyai, para ustadz dan ustazah serta pengurus pondok pesantren dan sedangkan objeknya beberapa siswa. Sumber data yang peneliti gunakan adalah sumber data primer dan sumber data sekunder. Sumber data primer adalah data yang diperoleh atau dikumpulkan oleh peneliti dengan cara langsung dari sumbernya. Adapun sumber data primer tersebut data yang didapatkan dari hasil pengamatan peneliti dan wawancara terhadap guru akhlak dan siswa di Pesantren Modern El-Alamia. Data sekundernya diperoleh peneliti dari sumber yang sudah ada berupa bukti, catatan dan file dalam pengumpulan. Dalam hal ini data yang dimaksud yaitu data yang berkaitan dengan implementasi pendidikan karakter dengan kebiasaan dan keteladanan di Pesantren Modern El-Alamia.

Metode Pengumpulan data dilakukan untuk memenuhi kebutuhan informasi agar data yang diolah bisa dipertanggung jawabkan dan memiliki hasil yang valid. Adapun metode pengumpulan data yang digunakan dalam penelitian ini adalah:

1. Observasi

Langkah teknik pengumpulan data ini, peneliti mengadakan pengamatan, baik secara langsung ataupun tidak langsung tentang hal-hal yang telah diamati, kemudian dicatat. Selain itu menurut Nawawi dan Martin (Afifuddin dan Saebani, 2012) mengatakan bahwa observasi adalah pengamatan dan pencatatan secara sistematik terhadap unsur-unsur yang tampak dalam suatu gejala atau gejala-gejala dalam obyek penelitian. Metode observasi penulis gunakan untuk mendapatkan data letak geografis sampai keadaan gedung sekolah, kegiatan pembelajaran di kelas, kegiatan keseharian santri di asrama, pelaksanaan pembiasaan dalam upaya menumbuhkan karakter dan perilaku yang baik pada siswa di pesantren terkait dengan pendidikan karatker pada santri.

\section{Wawancara (Interview)}

Teknik penelitian ini dilaksanakan dengan cara melakukan kegiatan tanya jawab baik secara langsung ataupun tidak langsung dan dapat melalui media apa saja antara pewancara dengan nara sumber sebagai sumber informasi. Wawancara didefinisikan sebagai kegiatan tanya jawab antara dua orang atau lebih untuk mendapatkan informasi dan ide, sehingga bisa dibangun informasi yang valid dalam satu topik. Kegunaan metode wawancara ini adalah untuk mendapatkan data bagaimana pendidikan karakter di pesantren ini diterapkan melalui pembiasaan dan keteladanan serta faktor pendukung dan penghambatnya. Adapun yang menjadi nara sumbernya yaitu kyai dan wali keas untuk mengetahui respon mereka terhadap metode 
pembiasaan serta keteladan dari pihak pesantren serta sejauh mana santri telah melaksanakan pembiasaan yang ada di pesantren.

3. Metode Dokumentasi

Metode ini dapat dilakukan dengan cara mengumpulkan berbagai macam data berupa buku-buku, catatan-catatan, notulen,surat kabar, agenda, dan sebagainya. Dokumentasi dapat berupa catatan, foto, rekaman suara, ataupun rekaman vidio. Peneliti menggunakan metode ini untuk memperoleh data jumlah santri, guru dan karyawan, struktur organisasi, sarana dan prasarana, letak dan keadaan geografis di Pesantren Modern El-Alamia 2019/2020.

4. Metode Analisis Data

Yang dilakukan dalam metode ini yaitu menyusun data secara sistematis berdasrkan dari hasil observasi, wawancara, dan bahan lainnya, untuk mendukung pengambilan keputusan dan kemudian hasil penelitiannya dapat diinformasikan kepada orang lain. Untuk mengukur analisis data yang diperoleh penulis menggunakan analisis induktif. Analisis induktif menganalisa dari faktor-faktor khusus, kemudian fakta itu ditarik kesimpulan yang bersifat umum.

Peneliti mengambil teori analisis data dari Miles dan Huberman (Sugiyono, 2012) tahapan analisis data meliputi tiga alur kegiatan, yaitu reduksi data, penyajian data dan penarikan kesimpulan/ verifikasi.

1. Reduksi data: yaitu proses pemilihan data, merangkum, memilih data yang pokok, memfokuskan pada data yang penting, dicari tema dan polanya dan membuang yang tidak perlu.

2. Penyajian data (data display) : Dalam penyajian data ini, dengan mengelompokkan data yang semacam kedalam bentuk teks yang bersifat penjelasan juga dapat berupa tabel, grafik sehingga mempermudah dalam penarikan kesimpulan.

3. Penarikan kesimpulan: setelah dilakukan pengumpulan data dan analisis data , tahap selanjutnya adalah interpretasi yang kemudian disusun dalam kesimpulan.

\section{RESULTS \& DISCUSSION}

\section{Results}

\section{Nilai-nilai Pendidikan Karakter}

Sumber-sumber nilai yang digunakan dalam penerapan pendidikan karakter bangsa di sekolah yaitu : Agama, Pancasila, Budaya, Tujuan Pendidikan Nasional, dan Undang-undang Republik Indonesia Nomor 17 Tahun 2007. Pengembangan penguatan pendidikan karakter berlandaskan Pancasila dengan memprioritaskan 5 karakter utama yaitu religius, nasionalis, integritas, mandiri, dan gotong royong. Di pondok pesantren sudah mencakup keseluruhan dari kelima kerakter tersebut. Dengan berbagai macam kegiatan dari mulai bangun tidur hingga malam kembali tidur semua terjadwal.

Para santri wajib bangun pukul 3 dini hari dan tidur malam sebelum jam 10 malam. Di pondok pesantren mereka di jadwalkan dengan serangkaian kegiatan yang berm anfaat mulai dari beribadah, belajar, bergaul, bersikap, dan diwajibkan menjadi pribadi yang disiplin serta mandiri. Dengan tinggal di asrama santri harus mampu memenuhi kebutuhannya sendiri. Santri harus bisa mendisiplinkan diri dengan mengatur waktu sebaik mungkin agar seluruh kegiatan dan tugas dapat diselesaikan.

Tujuan pendidikan pesantren untuk mengembangkan serta menciptakan kepribadian yang sesuai dengan ajaran agama Islam, yaitu kepribadian yang beriman 
kepada Tuhan, kepribadian yang bertaqwa, memiliki akhlak mulia, bermanfaat di masyarakat dengan membaur serta menjadi abdi masyarakat. Di pondok pesantren yang menjadi teladan para santri yaitu kiai dan tenaga pengajar (ustad) di pondok pesantren tersebut yang telah berkompeten untuk mengajarkan berakhlak dan berilmu. Keteladanan juga didapat para santri dari kebiasan yang dibangun selama di pesantren. Seperti di pondok pesantren El Alamia ini memberikan toleransi batas waktu 3 bulan bagi santri baru untuk mengenal, memahami dan membiasakan diri dengan kegiatan di pesantren. Setelah lebih dari tiga bulan, santri baru di anggap telah mampu memahami dan wajib menjalankan kebiasaan yang dilakukan di pesantren dengan serangkaian kegiatan dari mulai bangun tidur hingga menjelang tidur. Jika santri lalai maka akan diberikan hukuman sebagai sanksi atas kelalaiannya. Biasanya hukumannya berupa membereskan kamar teman atau membersihkan kelas.

Nilai-nilai pendidikan karakter yang dibangun melalui pembiasaan yang dilakukan para santri di pondok pesantren akan melekat hingga santri tamat belajar dan bahkan hingga dewasa. Karena kebiasaan yang telah dilakukan dalam waktu yang lama sulit untuk ditinggalkan.

\section{Pentingnya Pendidikan Karakter}

Seperti yang telah kita ketahui bersama, di Indonesia saat ini mengalami penurunan kualitas moral, terutama dikalangan anak usia sekolah. Mendasar pada kodisi tersebut perlu diberikan dan diterapkan pendidikan karakter di sekolah. Sekolah diwajibkan memberikan kontribusi dan tanggungjawabnya untuk mengembangkan dan menanamkan karakter yang baik sehingga mampu membantu membentuk dan membangun karakter siswa dengan perilaku yang baik.

Pendidikan saat ini seharusnya berpusat kepada peserta didik/siswa, dan peran guru sebagai pendidik harus mampu memberikan stimulasi terhadap siswa agar mampu menganalisis dan bisa berfikir secara kritis. Dengan metode tersebut secara tidak langsung pendidik dapat mengembangkan karakter pada siswa untuk berkreasi. Generasi mendatang yang terjun di dunia politik akan terhindar dari sikap korupsi dan mampu menjadi pemimpin yang lebih mengedepankan rakyatnya sehingga bisa menjadi pemimpin yang berakhlak mulia, bertanggung jawab, jujur, jika pendidikan karakter di dalam dunia pendidikan dapat diterapkan secara maksimal. (Fatim Zahroh,2017)

Pendidikan karakter diterapkan di sekolah untuk memberikan tekanan pada nilai-nilai tertentu seperti rasa tanggungjawab, peduli, jujur, dan adil dan membantu siswa untuk memperhatikan, memahami, dan mempraktekan nilai karakter tersebut dalam kehidupan sehari-harinya untuk mencapai kesuksesan hidup. Berdasarkan hasil penelitian psikologi sosial, memberikan hasil bahwa orang yang sukses di dunia ditentukan oleh peranan ilmu sebesar $18 \%$, dan sisanya $82 \%$ ditentukan oleh keterampilan emosional, soft skill (karakter), dan sejenisnya. (Elfindri, 2011).

\section{Discussion}

Implementasi Pendidikan Karakter di Pesantren Modern El-Alamia melalui Keteladanan dan Pembiasaan. Membangun karakter manusia tidak mudah, tidak seperti membalik telapak tangan. Kebiasaan dan keteladaan merupakan dasar ilmu yang wajib diperoleh oleh siswa untuk digunakan di dalam bermasyarakat sehingga akan membentuk karakter yang kuat, dan bermanfaat bukan hanya untuk dirinya sendiri, tetapi juga untuk orang lain. 


\section{Implementasi Pendidikan Karakter}

1. Karakter Religius

Pendidikan karakter religius dengan pembiasaan dilakukan dengan membiasakan santri berdoa sebelum dan sesudah melakukan aktivitas. Santri melaksanakan salat wajib secara berjaamaah. Mereka juga melakukan salat tahajud pada setiap malam. Pondok juga melakasanakan kegiataan kegamaan (hari besar islam), seperti perayaan Maulid Nabi. Para santri diarahkan dan dibiasakan untuk membaca doa bersama di dalam kamar sebelum tidur. Setiap akhir tahun akademik diadakan pekan perkenalan khutbatul arsy (PPKA).

Pendidikan karakter religius melalui keteladanan dilakukan oleh kiai/pengasuh pondok pesantren dengan memimpin salat duha berjamaah. Kiai/pengasuh pondok pesantren juga memberikan pengarahan dan penjelasan kepada seluruh ustaz dan ustazah mengenai ketentuan-ketentuan dalam mengasuh santriwan dan santriwati. Para ustaz dan ustazah dengan memberikan teladan dalam berkomunikasi antara ustaz dan santri sehingga terjalin komunikasi dua arah yang baik dan sesuai dengan yang diperintahkan dalam agama. Pemberian irsyadat dan taujihat oleh ustaz dan ustazah kepada seluruh santri di masjid setelah pelaksanaan salat isya. Teladan yang dilakukan oleh kakak kelas (senior) dengan cara membimbing adik-adik kelasnya dalam kegiatan ibadah maupun dalam kegiatan belajar.

2. Karakter Nasionalis

Pendidikan karakter nasionalis para santri dengan pembiasaan dilakukan dengan melaksanakan kewajiban dalam disiplin yang telah ditentukan bagi yang tidak mengindahkan diberikan sanksi yang berlaku pada setiap jenis pelanggaran. Para santri berada di dalam kamar dan segera beristirahat ketika bel tidur berbunyi, memberikan identitas nama pada perlengkapan santri, lemari wajib digembok, kamar wajib dikunci dari dalam ketika jam tidur berlangsung, dan dikunci dari luar ketika KBM berlangsung. Petugas piket siang dan malam wajib berada di depan kamar setelah kegiatan bersih area pondok,kecuali ada keperluan mendesak. Ketua kamar dan petugas piket bertanggung jawab apabila ada barang hilang di dalam kamar. Ketua kamar berperan aktif dalam keamanan dan disiplin pondok, kebersihan dan kerapian kamarnya.

Pendidikan karakter nasionalis para santri dengan keteladanan dilakukan dengan mengucapkan salam pada sesama teman dan cium tangan ketika bertemu dengan kakak kelas, tamu, asatidz, dan bapak pimpinan pondok. Santri mengucapkan salam ketika masuk kamar dan kelas. Ketua kamar memimpin pembacaan doa sebelum dan sesudah tidur. Seluruh santri diwajibkan menjaga kebersihan lingkungan pondok dan kamar. Santri memakai seragam (bet, sepatu, dasi, peci, sabuk, dan kaus kaki) ketika kegiatan belajar dan kegiatan pramuka. Santri memakai celana panjang ketika tidur dan keluar kamar. Para santri berperan aktif dalam mengikuti kegiatan MTQ (musabaqoh tilawatil qur'an), pidato dalam tiga bahasa antarpondok pesantren.

\section{Karakter Integritas}

Pendidikan karakter integritas para santri dengan pembiasaan dilakukan dengan tidak berkata kasar, jorok dan provokatif. Santri tidak tertawa berlebihan dan tidak memanggil dengan sebutan yang buruk kepada temannya. Para santri tidak diperkenanakan memakai peralatan santri lain tanpa seizin pemiliknya. Santri membawa surat keterangan jalan ketika izin keluar pesantren dan tidak melakukan kegiatan di luar keterangan yang tertera di surat izin. Santri melapor ke bagian 
keamanan dan pengasuhan setibanya di pesantren setelah melakukan kegiatan di luar pondok pesantren. Barang-barang santri yang hilang wajib dilaporkan kepada bagian keamanan dan pengasuhan pondok. Santri yang menemukan barang santri lain yang lain wajib menyerahkan ke bagian keamanan pondok. Setiap ada santri menyontek akan diberikan sanksi sesuai dengan aturan yang berlaku.

Pendidikan karakter integritas para santri dengan keteladanan dicontohkan oleh pimpinan pondok, ustaz dan ustazah, dan santri-santri senior melalui ucapan, sikap, dan perilaku yang sesuai dengan norma-norma yang sudah ditentukan. Pimpinan pondok dapat memberikan nasihat dan motivasi bagi para ustaz dan ustazah untuk menjaga silaturahmi dengan warga pondok dan di luar pondok. Dalam pola pembelajaran di kelas, ustaz dan ustazah wajib menerapkan pola pembelajaran yang menyenangkan sehingga tercipta pembelajaran yang kondusif.

\section{Karakter Mandiri}

Pendidikan karakter mandiri para santri dengan pembiasaan dilakukan dengan melaksanakan kegiatan mencuci pakaian oleh masing-masing santri, mencuci peralatan makan, membersihkan perlengkapan tidur, menjaga kebersihan lemari, dan menjaga barang berharga masing-masing. Para santri dibiasakan untuk bisa berbicara di depan orang banyak melalui kegiatan latihan pidato (muhadoroh) setiap malam Jumat.

Pendidikan karakter mandiri para santri dengan keteladanan dilakukan oleh ketua rayon dengan cara menjadi konsultan bagi santri yang membutuhkan arahan dan bimbingan. Para pengasuh santri melaksanakan kegiatan rutinitas pondok lebih awal seperti bangun tidur lebih awal dan mandi lebih awal. Ustaz dan ustazah datang lebih awal ketika proses pembelajaran akan berlangsung.

\section{Karakter Gotong Royong}

Pendidikan karakter gotong royong para santri dengan pembiasaan dilakukan dengan melaksanakan kegiatan membersihkan kamar sesuai dengan jadwal yang dibuat. Para santri melakukan kerja bakti membersihkan lingkungan pondok sesauai dengan jadwal yang sudah ditentukan. Santri berbagi makanan dengan teman-temannya ketika mendapatkan makanan dari orang tuanya. Santri meminjamkan peralatan kepada temannya ketika peralatan temannya rusak atau hilang. Santri saling menjaga satu sama lain dari gangguan dan ancaman yang datang dari luar pondok. Masing-masing santri tergabung dalam konsulat (asal daerah masing-masing) yang akan memfasilitasi santri tersebut ketika santri tersebut akan pulang di masa liburan pondok.

Pendidikan karakter gotong royong yang dilakukan oleh lembaga pondok melalui keteladanan seperti, mengadakan kegiatan sosial untuk membantu warga sekitar pondok ketika terjadi musibah.

Teladan untuk santri di pesantren yaitu ustadz/ustadzah, sedangkan di dalam agama Islam sendiri terdapat suri teladan yang patut kita contoh yaitu Nabi Muhammad SAW. Dengan mendekatkan santri kepada agama serta terus menerus mengingatkan terus kepada kebaikan, melakukan kebiasan yang baik, sampai harus berkata yang baik akan merubah dan mengarahkan santri kepada karakter yang baik.

Dengan pendidikan karakter yang diterapkan di Pondok pesantren El Alamia ini santri diutamakan dekat dengan Agama karna diajarkan rajin beribadah dan pengaplikasiannya dalam kehidupan, berakhlak baik dengan menjaga tata krama serta sopan terhadap yang lebih tua, saling tolong menolong karna harus melaksanakan kerja bakti dalam kegiatan Jumat bersih, memiliki toleransi yang tinggi karna hidup dengan banyak teman dari tempat asal yang berbeda suku,mampu mandiri karna jauh dari 
keluarga. Karena itu implementasi pendidikan karakter di Pondok pesantren lebih tepat sasaran dan menghasilkan peserta didik yang terbangun secara karakter.

\section{CONCLUSION}

Pendidikan karakter merupakan sebuah proses pengubahan sifat, akhlak, budi pekerti,mental, dan jiwa seseorang agar berkembang menjadi dewasa (manusia seutuhnya). Pendidikan karakter bertujuan membentuk generasi penerus bangsa yang tangguh, bertoleran, kompetitif, berjiwa patriotik, berakhlak mulia, bermoral, bergotong royong, berkembang secara dinamis, berorientasi ilmu pengetahuan dan teknologi yang semuanya dijiwai oleh iman dan takwa kepada Tuhan Yang Esa berdasarkan pancasila.

Pendidikan karakter diarahkan untuk membentuk kelima nilai dasar karakter manusia yaitu religius, nasionalisme, kemandirian, integritas, dan kegotongroyongan serta membantu siswa untuk memahami, memperhatikan, dan mempraktikan nilai-nilai tersebut dalam kehidupan siswa sendiri untuk mencapai kesuksesan hidup dimasa depan. Pendidikan karakter di sekolah dapat diterapkan melalui keteladanan yang dilakukan guru dan juga dapat ditanam melalui pembiasaan secara terus menerus.

Di Pesantren Modern El-Alamia ini telah menerapkan penguatan pendidikan karakter melalui pembiasaan yang dilakukan secara rutin oleh para santri dan keteladan yang dicontohkan oleh para kiai, utadz/ustdzah, dan pengurus di pondok pesantren. Pembiasaan dan keteladanan ini dilakukan dalam jangka waktu yang lama. Bergantung dari lamanya santri mengikuti pembelajaran di Pondok.dengan begitu pendidikan karakter yang telah diperoleh para santri akan melakat hingga tua nanti.

Dasar karakter manusia adalah akhlak. Jika manusia diberikan pendidikan akhlak yang baik sejak dini dimulai dari keluarga hingga di sekolah dan di masyarakat akan menghasilkan manusia yang berkarakter kuat yang mampu menjadi pemimpin diri sendiri dan pemimpin bagi orang banyak. Pemimpin yang berakhlak baik dan berkarakter kuat akan membawa ke arah yang lebih baik.

\section{REFERENCES}

Afifuddin dan Saebani, Beni Ahmad. (2012). Metodologi Penelitian Kualitatif. Bandung: Pustaka Setia.

Amin, M.M. (2015). Pendidikan Karakter Anak Bangsa.Yogyakarta: Hak Cipta.

Aminulloh, Y. (2014). Ubah Mindset Pembelajaran. Yogyakarta: Aswaja Pressindo. .

Chatib, M. (2014). Gurunya Manusia. Bandung: Kaifa Learning.

Daryanto, D. (2013). Implementasi Pendidikan Karakter di Sekolah. Yogyakarta: Gava Media.

Departemen Agama RI. (2010). Al-Qur'an dan Terjemahnya. Bandung: PT. Sygma Examedia Arkanleema.

Dharma, K., dkk. (2011). Pendidikan Karakter : Kajian Teori dan Praktik di Sekolah. Bandung :Rosda Karya

Djaali. (2013). Psikologi Pendidikan.Jakarta: Bumi Aksara.

Elfindri. (2011). Soft Skill untuk Pendidik. Jakarta: Baduose Media.

Fadhl. (2012). Bersama Rasulullah Mendidik Generasi Idaman. Jakarta: Pustaka Iman Asy-Syafi'i.

Hamka. (2017). Akhlaqul Karimah. Jakarta: Gema Insani

Hasan. (2012). Pedoman Pendidikan Karakter pada Pendidikan Anak Usia Dini. Jakarta: PT Bumi Aksara. 
Hidayat, S. (2013). Teori dan Prinsip pendidikan. Tangerang: Pustaka Mandiri.

Koesoema, D. (2011). Pendidikan Karakter: Strategi Mendidik Anak di Zaman Global. Jakarta: Grasindo.

Mulyasa. (2012). Manajemen PAUD. Bandung : Remaja Rosdakarya.

Sanjaya, W. (2013). Penelitian Pendidikan Jenis Metode dan Prosedur. Jakarta: Prenada Media Group.

Santoso, A. (2012). Nafas Kreatif-Inovatif-Aktif (KIA) Dalam Pembelajaran Bahasa dan Sastra Indonesia. J-TEQIP Jurnal Peningkatan Kualitas Guru, 104.

Sugiyono. (2012). Metode Penelitian Pendidikan: Metode Kualitatif, Kuantitatif dan $R \& D$. Bandung: Alfabeta.

Syafri, U.A. (2012). Pendidikan Karakter Berbasis Al- Qur'an. Jakarta: PT Raja grafindo Persada.

Zahara, T. (2016). Landasan pendidikan. Jakarta: PT Pustaka Mandiri. Hal.171

Zahroh, Fatim. (2017). Pentingnya Pendidikan Karakter dalam Dunia Pendidikan. www.kompasiana.com (diakses tanggal 8 Februari 2021)

Zainal, A. (2012). Pendidikan Karakter di Sekolah. Bandung: Yrama Widya. 